閵シテモ余等ハ語意作成時ノ子至二就テノ立場 尹或八波形ヨリ。或八「レ」線像等ヨリ。或八 解析ノ結果等ヨリ多少說述セント欲スル。 而シテ最後二鼻音ノ分類八何二由來スルカ二關 シテ考察シ。之が賽二後續子吾ノ種類二低ルモ クデナリ. 如何ナル後續子百ノ場合二如何ナル 鼻昔ガ必然的二發㱏サル、カ二就テ詳述スルト 共二. 夫等ノ鼻畐八更二高舌及ビ低活，二樣， 發音法二传り．音色的二更二細目ノ分類 得儿事习提唱シ. 晌ホ斯カル分類八舅音が歌馨 二應用サル、場合二．韾葲的意義フモ有スル事 习說述七り。

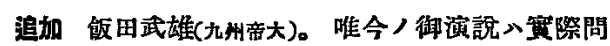

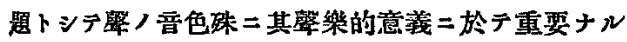
モノト信ズ。其中二於フ高舌及ビ低舌二於ヶル鼻音 こ於テ・「フォルマント買Уテ現ハル。即チ．前者 二於テ. 高位ノモノ現ハルトノ結果伺七タ日。今 此现象/成立機德二就テ考フルニ. 共鸣腰/固有振

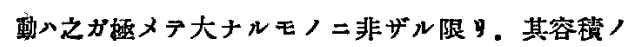
本方根二逆比例スルト云フ物 理學的法則卜關醉シ

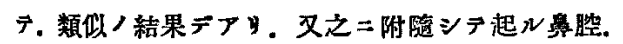

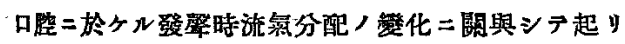
タルント思惟ス。

\section{5. 諸軧發㢣器疾患ニ於ケ几㹂域ノ}

觀察飯 由 武堆(杂州) 過去 3 回ノ本會總會二於テ，余八「日本人韾 域」=關シ，其生理的狀態二就テ述ブル處アリ タリ。此度八引續キ諸種發䠛器痑患二於ケル場 合. 即チ病的狀態トシテ，馨域

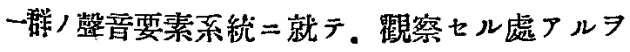
以テ其概要フ報告セン。

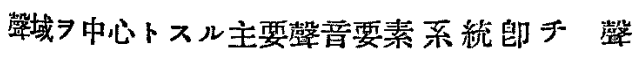
域：談話曋．馨律摆 (上向性及ビ下向性)。中間

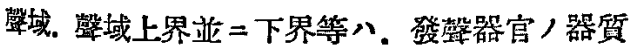
性椾二機能性疾㭧二依り。著シク或ハ少シク影
響變㢦セシメラル、モノナリ。余八教年間，九

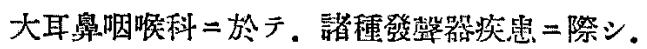
㢣域其他之等一群ノモノガ如何ナル程度二變化 セルモノナリヤ. 久疾病，恢復、經過等卜共二 如何二䇾移スルモノナルカラ. 其計测七ル音位 數值ニ據りテ考察シタリ。

疾患トシテハ、慢性喉頭炎. 謡人結節。綮帶

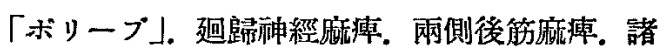

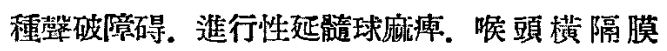
症. 峧頭癌等. 總数 60 例。之等二就テ得タル昔 位數值ハ煩権ナル故. 一タ之ヨ記サズ概要結論 ヨ述ブ。

概諭的 =言一パ．之等，中．機能性ノモノ八視 舅的所見，㜔碍程度卜罄域群卜，關係八一見一

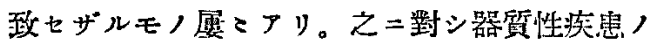
モノ八、多ク八局所所見卜頻似性ノ變化 7 示 ス。䇫律堺ハ之 7 確定スル事困難ナル場合多 シ。談話畐八通常音位卜大差無キモモアレ ド、變移セルモ，二於テハ，低豆方=移動セル モ, 比較的多キカ二見工。韾域下界八想像二反 シ上景セルモノ少ク.多數二於テ八通常位二止 マルカ 寧口稍マ下降七ルモノフ認ム。之二引

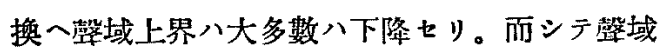

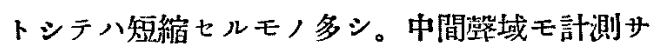
レタル籍圍二於テハ概六縮小七り。又談話亘二 2 個ノ相離レタル㱏位ヨ示スモノアリ或八上昇 セルモノアリ。之等八監破障碍二屡り認メラ ル。

以上ハ概括的二見タル結果ナレド，各疾患別=

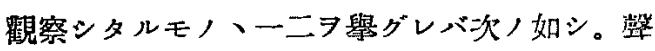
率「ポリープ」一馨域短縮ノ程度八 通㹕的二見 テ約 5 「牛音」(男子)ナりキ。警域下界ヨリモ 警域上界，變野多ク認メラル(上界，下降)。又 
女子ニ於テハ，下界ノ下隆七ルモノ霆とアリ。 慢性喉頭炎一馨域縮小七ルモ，極メテ多キガ如 シ。

网側後筋尤瘦一症例少ヶレモ，上界，下降稍 稍著シク、嗻域モ短縮七リ。

喉頭癌一程度二依り種々異レドモ，常二縮小七 ル㢣域認ム。

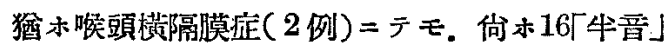
以上/㢣域

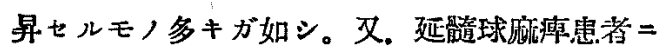
於テハ下界ノ上䒜七ルモノ認メラル。 次二治療二應ジ。經過的二見タル場合（主トシ テ警帶「ポリープ」二於テ）治療後二於テ多。

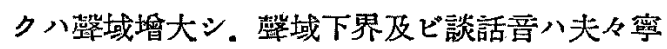
口稍ミ上昇セルモ，比較的多シ。何示韾破障碍 ノ如キ場合ニ八. 談話音ノ下隆七ルモノ 後二見山。

要スルニ，一般的二通觀シテ。馨域系統。正常 脶態二近キ迄二饭復スルモノモアレドモ。中二 八佾ホ正常值ヨリモ劣少ナリ。或八尚ホ多少之 ヨリ變移セリト思ハル、䟮態二轉歸スルモ，

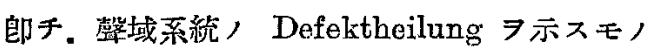

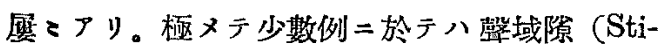

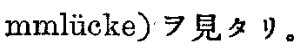

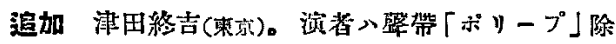
去後二㢣域/上暴キ見タル症例アルコトキ逝ベラレ

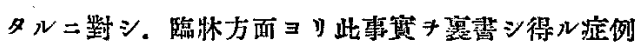
二三キ追加セントス。症例 入靲レモ㢣率「ポリー

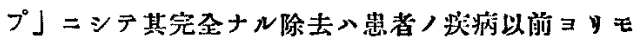

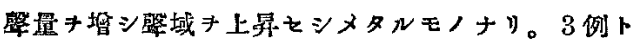
モ要學的釈者ナり。何ホ此機會=「ポソープ」除去

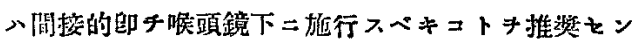
$r>0$

類題 諸種番馨職業家/緊晋障碍

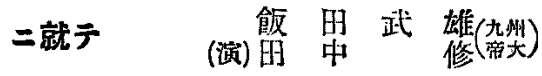

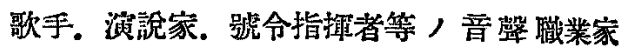
二於ケル銥吾障碍二關シテ泰西ニテハ. フレ

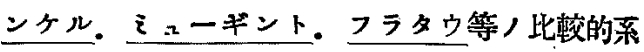

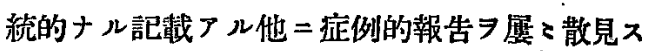
ル所ナルモ. 我國=テハ斯カル方面，璧意學的

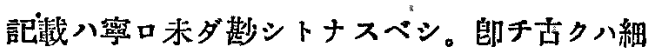
谷氏ノ㓡樂家 4 名ノ馨音㜔碍二就キテ報告ア リ，近ク八站四氏，溥井氏．林氏．野村氏：白 岩氏。切替氏等ノ報告フリ。

元來豆㢣職桨家八總テ音㢣ノ過度使用二陷り易

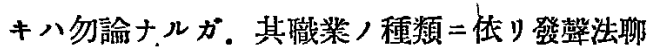
カ異儿等又 其障碍トシテノ韾音異常. 喉頭所 見モ常ニ八同仇ナラズ．其種類並=陪碍程度， 美異等ニ關シテ之ア見ル時ハ. 興味深キモうフ

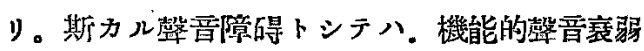

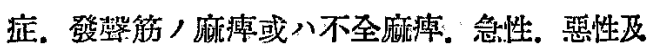
ピ慢性,喉頭炎. 謡入結節. 壁帶「ポリーブ」.

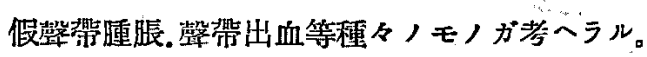

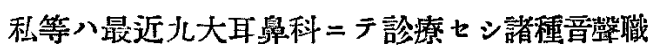

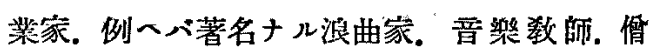

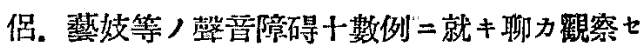
ル所アリショ以テ 簡單二一括シテ報告セムト スルモノナリ。之等 =就キテ八，喉頭鏡的检 查.「ストロボスコピー」.錄音.韾域檢查.「オ。 シログラフ」等/檢香ヨモナシ觀察セルモノ ナリ。之等；症例二於テハ殆ンド皆嗄繁ラ主訴 ト七り。温曲家ニテハ總テ韾帶前 $1 / 3$ / 璄界 部 $=.2$ 例八兩側 $=.1$ 例八一側 =陆人結節 7 有シ. 刃. 慢性喉頭炎ノ所見フリ、「ストロボス

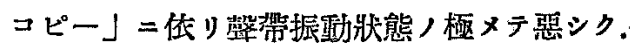

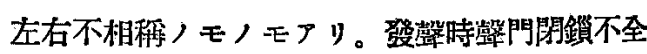
アルラ認メタリ。售侣ニテハ，7名中 2 例ハ 1

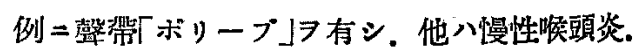

